\title{
The Shell Motif in the Culture and Architecture of the Ancient Town of Marina el-Alamein in Egypt
}

\author{
Grażyna BĄKowsKa-Czerner, RaFAŁ Czerner
}

\begin{abstract}
At the archaeological site of Marina el-Alamein in Egypt, many monuments and everyday objects feature motifs related to Aphrodite and her cult. One recurring theme is the seashell that lamps are often decorated with. In one case, it accompanies the depiction of the goddess herself. This article collects oil lamps with the image of a scallop shell from the research of the Polish-Egyptian Conservation Mission, as well as already published specimens from earlier archaeological research. It has been noted to date that this motif is one of the most common on lamps found in Marina el-Alamein. Shells also appear on architectural elements - in the finials of niches with a religious purpose, located in the main reception halls of houses. In such aediculae they are well exposed, but the use of shells does not arise from the shape of the architectural framing. Therefore, other reasons, possibly symbolic ones, for including this motif in decoration should be considered.
\end{abstract}

Keywords: Graeco-Roman Egypt, scallop shell, architecture, decoration, religion, Aphrodite, lamp, aedicula

Grażyna Bąkowska-Czerner, Centre for Comparative Studies of Civilisations, Jagiellonian University, Krakow; grazyna.bakowska-czerner@uj.edu.pl; (D) 0000-0002-8623-6545

Rafał Czerner, Department of History of Architecture, Art and Technology, Wrocław University of Science and Technology, Wroclaw; rafal.czerner@pwr.edu.pl; (D) 0000-0002-7567-4902

The ancient town discovered at the site of Marina el-Alamein in Egypt functioned from the second century $\mathrm{BC}$ until the fifth century, or perhaps even the beginning of the sixth century AD (Fig. 1). Its location on the Mediterranean coast, near Alexandria, on sea and land trade routes was of great relevance and influenced its development as a port as well as the cultural and religious syncretism that thrived there. ${ }^{1}$

\footnotetext{
${ }^{1}$ Bąkowska-Czerner, Czerner 2019b.
} 


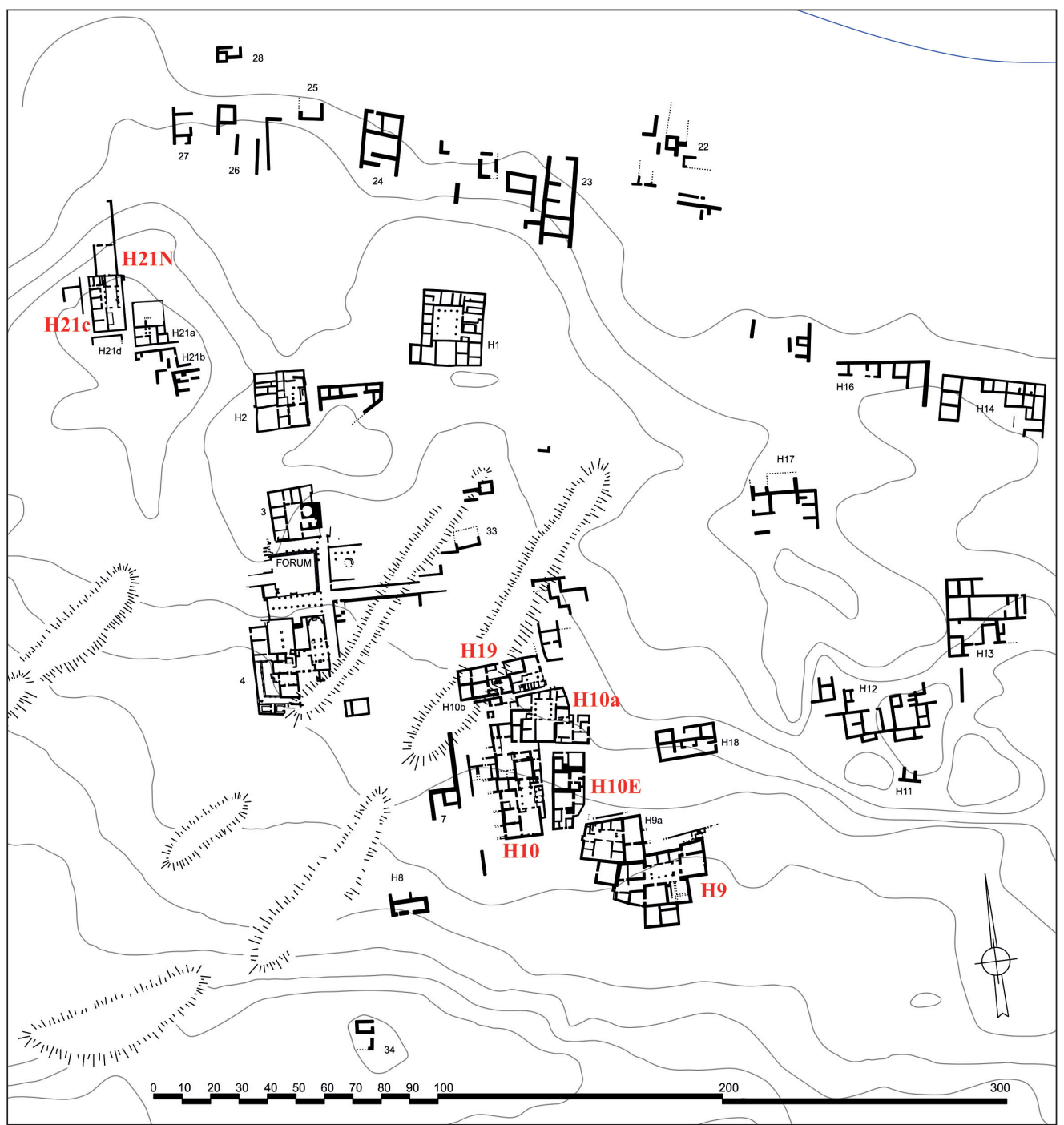

1. Marina el-Alamein. A plan of the central part of the ancient town with the houses marked where lamps or architectural decorations with a shell motif were found (Drawing: K. Majdzik, M. Krawczyk-Szczerbińska, R. Czerner).

The objects found at the site, mainly clay and glass vessels, come from various faraway places, but most are from Eastern Mediterranean regions, especially the Aegean islands. ${ }^{2}$ Many artefacts hail from Cyprus, including amphorae and lamps, but above all terra sigillata, whose popularity is also evidenced by many Egyptian imitations of Cypriot vessels. ${ }^{3}$

\footnotetext{
2 See: Majcherek, Zych 2011: 357-373; Kucharczyk 2010.

3 Cf. Daszewski 1995; Czerner, Bąkowska-Czerner, Majcherek 2015: 131-133.
} 
Numerous representations of the goddess Aphrodite found in Marina el-Alamein, ${ }^{4}$ underline also somehow association of this town with the Island. These are not only representation of the goddess herself, but also motifs related to the sea, including a dolphin and Eros on a dolphin. However, representations of scallop shells prevail, appearing not only on lamps, but also in domestic religious niches. In ancient art, images of Aphrodite being born from a scallop shell, sitting, or lying upon it are rather common, usually accompanied by various sea creatures. ${ }^{5}$

In Egypt, the cult of Aphrodite developed during the time of Ptolemies, and particularly Ptolemy II, whose wife Arsinoe was identified with this goddess. Here, one might mention her temple situated, like many sanctuaries of Aphrodite, on the coast, on Cape Zephyrion in Egypt. ${ }^{6}$ Worship of the goddess of love was associated with sea trade. She was the protector of navigation and harbours. Her followers included sailors and merchants. Aphrodite had many nicknames related to the sea: Euploia, Epilimenia or Pontia. ${ }^{7}$ One of the paintings in Marina el-Alamein depicts a woman in a nautical crown. ${ }^{8}$ Perhaps this is a representation of Arsinoe II, Berenice II, or a personification of the port city. In Rome the cult of Venus was supported primarily by Julius Caesar and Octavian Augustus. ${ }^{9}$ The Julio-Claudian dynasty derived its origins from her. The cult and image of the goddess was used for political purposes. She patronised victories at sea. The conquest of Egypt, the development of the maritime trade that she guarded, served to boost her popularity. Prayers were offered to the goddess of the sea for a good, safe journey, as well as for profit from trade. Offerings were made in her sanctuaries, including shells. ${ }^{10}$

The shell motif appears in many cultures, and was associated with life-giving water, fertility, sexuality, love, happiness and immortality. In ancient Egypt, shells were worn as ornaments and amulets. ${ }^{11}$ Cowrie shells guaranteed fertility. ${ }^{12}$ In Greek art and culture, the most common image is the scallop shell, which is associated with Aphrodite.

\section{LAMPS}

This shell is one of the motifs that frequently decorated lamp discuses, ${ }^{13}$ especially from the mid-first century and in the second century. They were produced in Italy, North Africa,

\footnotetext{
${ }^{4}$ Apart from realistic representations, including marble sculpture, bronze and alabaster figurines, her image appears on a lamp and probably in a wall painting in the lararium of one of the houses. See: Daszewski 2013: 168-170, Figs 5-8; 1991: 102, n. 34, Fig. 9; Bąkowska-Czerner 2011: 97-109, Figs 1-6; Czerner, BąkowskaCzerner 2020: 327, Fig. 9.

5 E.g. De Carolis et al. 2012: 9-10.

${ }^{6}$ Demetriou 2010: 72-73.

7 Demetriou 2010: 74 .

8 Kiss 2008: 83, Fig. 4.

9 Kousser 2010.

10 Vallois 1929: 34-35; Theodoropoulou 2013: 210-211, 213; Martin 2017: 275.

11 Petrie 1914: 27-28, Pls XIV-XV.

12 Andrews 1994: 42, Figs 49, 69.

13 E.g. Bailey 1980: 84-85, Fig. 99; Walters 1914: 70, no. 472; 74, no. 498; 108, nos 718-721, Pl. XXIV; 114, nos 766, 768; 127-128, nos 841, 842; 151, no. 1004; 186, no. 1229; Bruneau 1965: 128 ,
} 
Anatolia, Cyprus, and Knidos. In Egypt, they were found in Alexandria, ${ }^{14}$ Saqqara, ${ }^{15}$ Karanis, ${ }^{16}$ and at the Marina el-Alamein site, where lamps with a scallop shell's image appear relatively often. Usually, a shell is featured on them as a single motif that fits well into the lamp's disk, and such specimens from Marina el-Alamein will be discussed first. Sometimes, however, a shell is an element of a scene. These will be presented second, while the study will be rounded off by an overview of lamps with stylised images of shells.

The lamps described here were discovered during works of the Polish-Egyptian Conservation Mission, with the exception of three earlier published specimens coming from the first seasons of archaeological research undertaken at the site. All these lamps were mould-made.

Seven lamps from Marina el-Alamein feature a discus decorated with the image of a scallop shell, whose hinge is always located above the nozzle. One of them, whose exact location of discovery is unknown, comes from the mid-first or second half of the first century AD. ${ }^{17}$ It has a longer nozzle decorated with volutes and is without a handle. The filling hole is located in the centre of the shell. The lamp is representative of the Loeschcke Type IV. It is made of dark clay and covered with a red-brown slip. Lamps of this type are found relatively often in Cyprus or Carthage, among other places. ${ }^{18}$

Like the lamp described above, the next two also feature a discus decorated with a scallop shell, but they differ mainly in the shape of the nozzle (Fig. 2). This time it is short and D-shaped. There are no ornaments in the form of volutes. According to Bussière's typology, the nozzles represent form 3 and it is also comparable to Loeschcke's nozzle-form L2. ${ }^{19}$ These lamps are categorised as Loeschcke Type VIII, ${ }^{20}$ and were produced in Italy and Africa, as well as in the eastern regions of the Mediterranean (inter alia in Egypt). ${ }^{21}$ Like the lamp described above, also these two were without handles. Both were found inside houses (H10 and H19). They have a small filling hole in the centre of the discus, and a round regular wick hole on the nozzle. Traces of soot indicate that they were actually used. The lamp from house H10 features red-brown slip made of light brown clay (Fig. 2a). ${ }^{22}$ The plain shoulder is separated from the discus by one circular groove, and their form is close to Loeschcke VIIb. ${ }^{23}$ Its underside is smooth. The second lamp,

nos 4607-4609, P1. 30; 132, no. 4641, P1. 31; Deneauve 1969: 144-145, nos 536-538, P1. LV; 159, no. 644, Pl. LXV; 165, no. 696, Pl. LXVII; 178, no. 797, Pl. LXXV; 180, no. 798, Pl. LXXV; Oziol 1977: 83-84, no. 178; Pl. 11; 120, nos 295-296, Pl. 17; 214-215, no. 635, Pl. 37; 226, nos 656-658, Pl. 37; Goethert-Polaschek 1985: 269-272, nos 226-233, Pls 21, 61, 62, 65, 66; Bussière, Wohl 2017: 87, no. 114; 88-89, no. 237; 160-161, no. 274; 289-290, no. 415. Cf. Collection Bouvier: Chrzanovski 2019: 102-103, M91-M96.

14 Kadous 1992: 232, nos 10, 18, Fig. 2.

15 Bailey 2001: 127-128, no. 17, Pl. XVII.

16 Shier 1978: 127, no. 357, Pls 6, 39.

17 Zych 2004: 78, no. E3924, Fig. 2.

18 Zych 2004: 78, n. 4.

19 Cf. Bussière, Wohl 2017: 195, Fig. 3; Loeschcke 1919: 237, Fig. 7.

20 See: Loeschcke 1919: 237-243.

${ }^{21}$ Bussière, Wohl 2017: 193-194. See also: Bailey 1988; Młynarczyk 2012.

22 Medeksza 1999: 20, Fig. 19, Pl. XXI.

${ }^{23}$ Loeschcke 1919: 213, Fig. 5. 


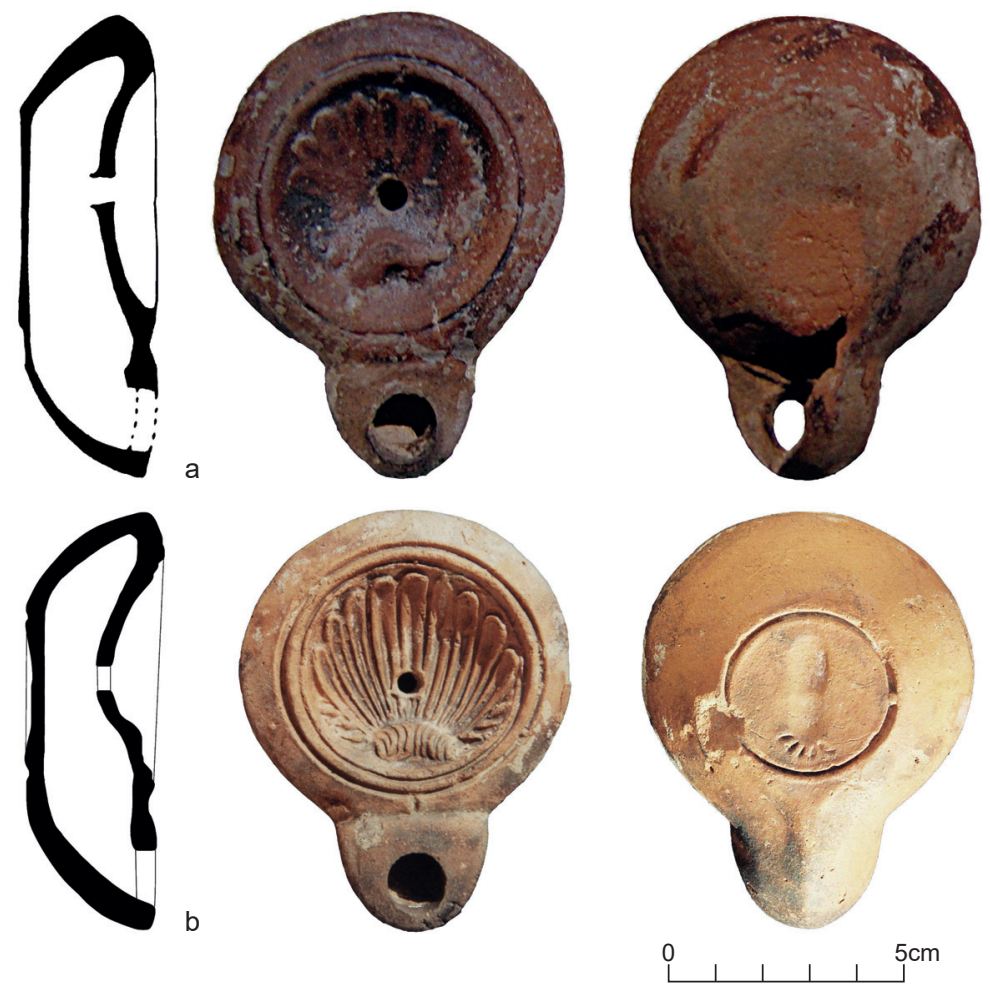

2. Marina el-Alamein. Lamps from houses H10 (a. inv. no. 6/H10/99) and H19 (b. inv. no. 95/H19/02) (Phot. A.B. Biernacki, P. Zambrzycki; drawing: A.B. Biernacki, G. Bąkowska-Czerner).

from house H19, differs in details from the one described above (Fig. 2b). It was found in room 16 in a context dated to the first-third century. There are faint traces of a dark red slip on the light brown surface. Two concentric grooves are visible between the shoulder and the discus. The shoulder is of Loeschcke form VIIa. ${ }^{24}$ On the base, surrounded by a circular groove, is a large planta pedis sign. This workshop mark tends to occur on African Loeschcke lamps from the first century, and on Eastern Mediterranean lamps from the second century. ${ }^{25}$ Planta pedis also appears on other lamps featuring the image of a scallop shell. ${ }^{26}$ Among them is one with a heart-shaped nozzle, from Anatolia, dating back to the second century. ${ }^{27}$ Summing up, on typological grounds these two lamps from Marina el-Alamein refer stylistically to the ones coming from eastern regions of the Mediterranean, and can be dated from the second half of the first century to the beginning of the second century.

\footnotetext{
${ }^{24}$ Loeschcke 1919: 213, Fig. 5.

${ }^{25}$ Cf. Bussière, Wohl 2017: 195.

26 Deneauve 1969: 144, no. 538, Pl. LV.

27 Bussière, Wohl 2017: 291-292, no. 415.
} 
Two lamps from Marina el-Alamein have discuses decorated with the image of a shell and heart-shaped nozzles (Bussière form 10; Loeschcke's nozzle form H). ${ }^{28}$ Both are covered in soot. Generally, these lamps are in the Loeschcke Type VIII. ${ }^{29}$ One, relatively small, is preserved in its entirety (Fig. 3a). It has a ring handle with two grooves in the upper part. The wick hole is not arranged symmetrically. The shoulder is decorated with small, delicate leaves in the form of three cut lines. The discus is separated from the shoulder by two concentric, relatively shallow grooves. The filling hole was located just above the hinge of the shell. The lamp is light brick in colour, and a reddish hue has been preserved inside just some furrows of the shell, maybe a trace of the slip that once coated it. It was found in house H10a in a context dated from the first century to the beginning of the third century. In form and decoration, it resembles a lamp from Karanis dating back to the second half of the second century, ${ }^{30}$ a lamp from Alexandria, ${ }^{31}$ and two specimens from the Bouvier Collection, attributed to the Alexandrian workshop and dated to the middle of the second century. ${ }^{32}$ The second example of a lamp with a heart-shaped nozzle and a shell decoration from Marina el-Alamein comes from room 17 of house H10E, from a context dating from the first century to the beginning of the third century (Fig. 3b). Unfortunately, only a fragment of it has survived. It is made of light brown clay. The shoulder are plain, again separated from the discus by two concentric grooves. The filling hole is located in the centre of the discus. On the shoulder above the nozzle, there is decoration repeating the heart-shape.

Although the nozzle of a still another lamp from Karanis is also similarly decorated, a sleeping Eros or Hypnos was depicted on the discus. It dates back to the second half of the second century. ${ }^{33}$ The same image can be found on some lamps from Marina el-Alamein. Here, again the representation of the scallop shell appears, but it is no longer the main motive. It fills the entire disk and is the background for the depiction of Eros. The god, naked, with large, spread wings is sleeping on a shell. His head rests on his left arm, and his right arm is positioned at the neck. The right leg is straight while the left leg is crossed, with the foot resting on the right foot. A small fragment of such a lamp has been preserved from house H10E, in a context dating to the first-second century (Fig. 3c). It is light brown, with traces of a reddish-brown colour slip or glaze only preserved in the furrows of the shell. The second lamp with such a decoration, discovered in one of the first seasons of research at the site, ${ }^{34}$ has a damaged nozzle and a handle that was probably ring-shaped. The shoulders are plain, with two circular grooves separating them from the discus. According to Zofia Sztetyłło, this is an imitation

\footnotetext{
28 Bussière, Wohl 2017: 195, Fig. 3.

29 Bailey Type Q, group ii; see: Bailey 1980: 339-341.

30 Shier 1978: 36-37, 127, no. 357, P1. 39.

31 Rosenthal, Sivan 1978: 43, no. 171.

32 Chrzanovski 2019: 270, M95, nos 389-390.

33 Shier 1978: 35-36, 124, no. 348, P1. 38.

34 Sztetyło 1991: 49, Fig. 7.
} 

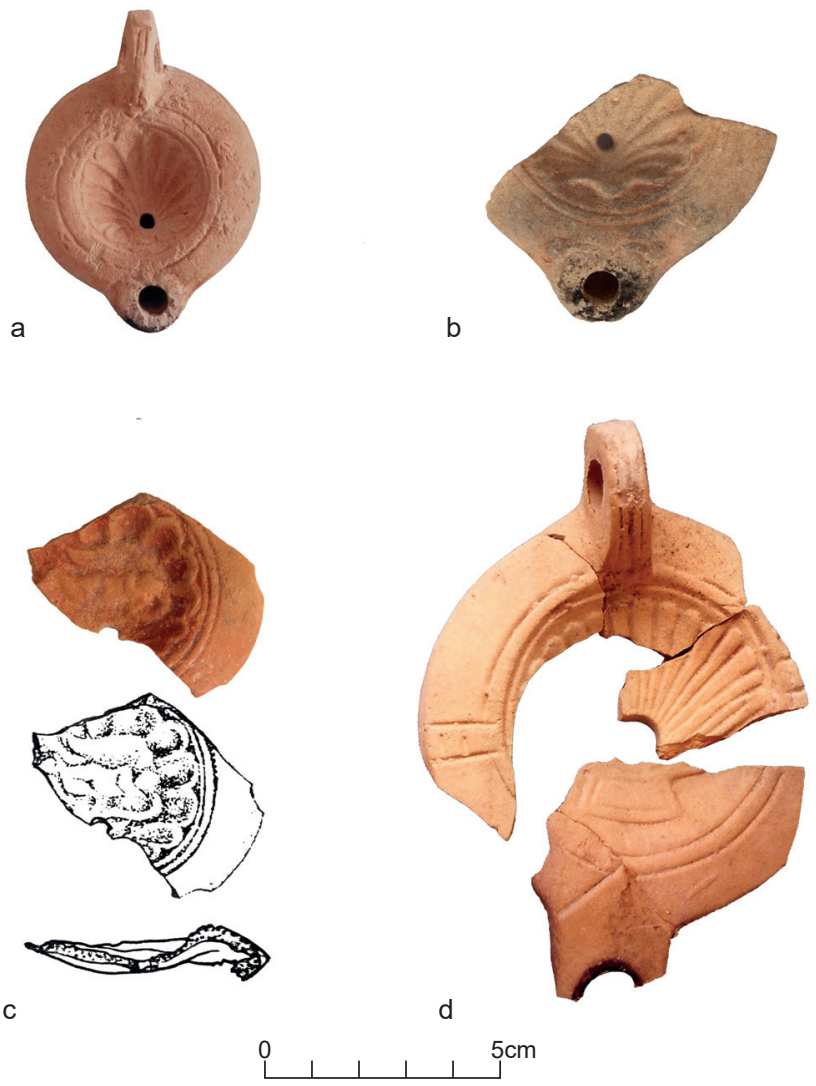

C

3. Marina el-Alamein. Lamps from houses H10a (a. inv. no. 58/H10a/03) and H10E (b. inv. no. 1/108/03; c. inv. no. 36/H10E/03; d. inv. no. 1/103/03) (Phot. W. Grzegorek, R. Czerner, G. Bąkowska-Czerner; drawing: M. Ujma).

of a lamp from the Hellenistic period, dating back to the middle of the second century to the third century. ${ }^{35}$

Louise A. Shier mentions that there are several lamps with this kind of decoration in the Graeco-Roman Museum in Alexandria, and they all bear the same sign - ears of grain and poppies on the bases. A similar lamp, now in the British Museum collection, comes also from Fayum. ${ }^{36}$ These lamps represent Loeschcke Type VIII, date back to the mid-second century and probably come from an Alexandrian workshop. ${ }^{37}$ The ears of grain and poppies refer to abundance and fertility, and are associated with Demeter, the goddess of harvest and agriculture, while the poppy itself is connected with sleep and is an attribute of Persephone. As to the image of sleeping Eros attested on above-mentioned lamps, it was widespread

\footnotetext{
35 Sztetyło 1991: 49.

36 Walters 1914: 178, no. 1182, Fig. 249.

${ }^{37}$ Chrzanovski 2019: 265, 269-270, nos 386-388, M23.
} 
in the sculpture of the Hellenistic period, ${ }^{38}$ but popular also in Roman times. Inter alia, it appears on tombstones, and funerary epigrams also refer to the sleeping god. ${ }^{39}$ The image of Eros or Hypnos sleeping on a shell is a popular Egyptian theme. ${ }^{40}$ The interpretation of the scene from the lamps may seem ambiguous. Sleeping Eros is a metaphor for eternal sleep as well as eternal love. ${ }^{41}$ The scallop shell on the described lamp is presented next to the motifs related to death, eternal sleep. One can also find it in the birth scenes of the goddess of love: from Egypt comes a lamp with the image of two Cupides taking Venus out of the shell. ${ }^{42}$ However, more often the scallop shell appears in scenes depicting Eroses and Venus 'at the bath'.

One of the lamps from Marina el-Alamein and dated from the second half of the first century to the beginning of the second century, which was found in a niche in room 16 in house H19, shows the image of the goddess of love accompanied by two Eroses (Fig. 4). ${ }^{43}$ The lamp is made of light brown clay and covered with a brown slip. It represents the Loeschcke Type IV. ${ }^{44}$ There is a regular wick hole in the nozzle. Volutes of a spiral shape are compressed between the nozzle and the discus, with an air hole above them. The lamp is damaged and the filling hole has not survived. Two concentric grooves separate the discus from the shoulder in the Loeschcke VIIa form. The ligatured letters A $\Gamma$ appear on the base marked off by a circular groove. Aphrodite is presented in the Anadyomene style. One Eros hands her a mirror, the other a scallop shell.

An identical representation appears on a lamp of the same type found in the Odeon in Corinth. ${ }^{45}$ It is dated to the second half of the first century, so corresponds to the date of specimen from Marina el-Alamein. Finally, this scene also appears on other types of lamps from the second century. ${ }^{46}$ It is attested on a lamp featuring a heart-shaped nozzle from the Piraeus Museum, ${ }^{47}$ and on a Corinthian lamp from Kom el-Shuqafa in Alexandria. ${ }^{48}$

In this context it should also be mentioned that Aphrodites with scallop shells appear often on lamps of various types from other sites or collections. On the lamp from Cartage, she is represented in the Anadyomene style against the background of a shell. ${ }^{49} \mathrm{~A}$ specimen, from Tunisia, depicts the goddess crouched in a bath with a seashell in her raised right hand, ${ }^{50}$ while on the lamp from Arles where Venus is combing her hair and holds a shell in

\footnotetext{
38 Hemingway, Stone 2017: 55-56.

39 Cf. Wypustek 2014.

40 Chrzanovski 2019: 75, M23.

41 Hemingway, Stone 2017: 57-58.

42 Chrzanovski 2019: 71, no. 464, M6.

43 Bąkowska-Czerner 2011: 107-109, Fig. 6A, B.

44 See: Loeschcke 1919: 225-228.

45 Broneer 1932: 140-141, no. 138.

46 Broneer 1932: n. 1.

47 Bruneau 1977: 258-259, no. 57, Figs 6-7.

48 Bruneau 1977: 259, n. 32.

49 Deneauve 1969: 165, no. 695.

50 Bussière, Wohl 2017: 178; another similar, see: Walters 1914: 204-205, no. 1364.
} 

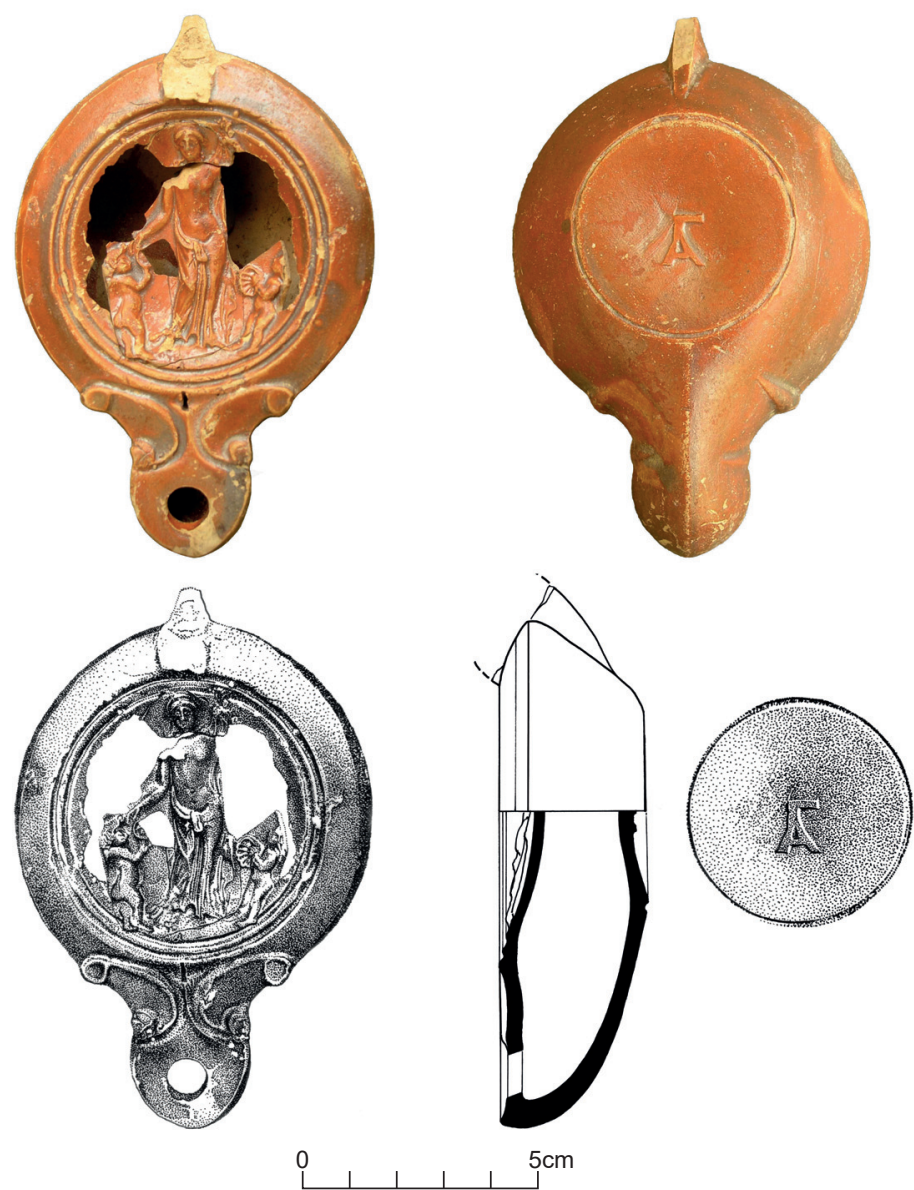

4. Marina el-Alamein. Lamp (inv. no. 77/H19/04) from house H19 (Phot. P. Zambrzycki; drawing: R. Czerner).

her left hand. ${ }^{51}$ Finally, on the discus of the lamp from Alexandria, the goddess is holding a cestus. On one side of her stands Eros and on the other is an image of a shell in a field. ${ }^{52}$

Finally, from Marina el-Alamein come fragments of two lamps with a stylised and geometricised image of a scallop shell on a discus, which dates from the middle of the second into the third century, and even fourth century. ${ }^{53}$ One of them was found in house $\mathrm{H} 10 \mathrm{E}$ in room 17 in a context dated to the first-third century (Fig. 3d), while the location where the second lamp was found is unknown. ${ }^{54}$ They are made of fine buff fabric and

\footnotetext{
51 Chrzanovski, Djaoui 2018: 87-88, M14.

${ }_{52}$ Walters 1914: 187, no. 1234, Fig. 271.

53 Zych 2004: 86.

${ }^{54}$ Zych 2004: 86-87, no. 280, Fig. 6.
} 
unslipped. The hinge in the form of a trapezoid and rectangular panels are visible on the shoulder. There is a V-shaped groove on the soot-blackened nozzle. A ring-shaped handle with three grooves in the upper part has been preserved. Such lamps have also been found on Cyprus in Larnaca, ${ }^{55}$ Xeros $^{56}$ and Palaepaphos ${ }^{57}$ They are similar to the Broneer type XXVII, Corinthian lamps with panels and trapezoid shaped groove on the nozzle. ${ }^{58}$

The lamps from Marina el-Alamein with the shell motif date from the middle of the first century to the mid-second century, except for two examples that come from the second-third century. Most of them seem to be imports, but there are also some Egyptian lamps. With the exception of three, whose detailed provenience is unknown, they were found inside houses. Three lamps with shell decoration were recorded in house H10E and two in H19. Individual examples come from houses H10 and H10a. Compared to other motifs that appear on the lamps from Marina el-Alamein, those with the image of scallop shells are among the most popular. The shell is shown as a single element or imagined with Eros/Hypnos, or with Aphrodite as her attribute. It seems that the inhabitants of the coastal, commercial town surrounded themselves with objects that alluded to the sea and the cult of Aphrodite.

\section{ARCHITECTURAL DECORATION}

The shell motif appeared in Marina el-Alamein also in architectural decorations. It can be found in architectural fixtures of aediculae for a religious purpose placed in the walls of the main reception rooms in residential houses. The shells were placed on the underside of the finials of the niches' architectural framing. Aediculae were made of limestone, the basic building material in the town, and two of them have retained traces of polychrome.

There are enough preserved elements to completely reconstruct the framing of four niches of different scales from the main rooms of the houses designated as $\mathrm{H} 9, \mathrm{H} 10, \mathrm{H} 21 \mathrm{c}$ as well as from a large room referred to as $\mathrm{H} 21 \mathrm{~N}$ that was in fact a separate building (Figs 5-6). ${ }^{59}$ Shell relics from the decorations of three of them (the niches from houses H9, H10 and H21c) have survived (Fig. 7). Two shells were carved into the stone surface of the niche's vault, while the third (H10) was moulded in stuccowork. This shell has retained traces of polychrome.${ }^{60}$ Both the shell and its background were blue, while the furrows on the hinge were dyed red (Fig. 8). The fourth aedicula, located in room H21N, did not have a shell

55 Walters 1914: 186, no. 1229, Fig. 267.

56 Oziol 1977: 214-215, no. 635.

${ }^{57}$ Bezzola 2004: 165, no. 308, Pl. 9.

${ }^{58}$ Cf. Bruneau 1971: 437-446.

59 The Polish-Egyptian Conservation Mission carried out an actual full anastylosis of niches in house H10, room $\mathrm{H} 21 \mathrm{~N}$ and partially in house $\mathrm{H} 9$. A very small aedicula from house $\mathrm{H} 21 \mathrm{c}$ was hewn entirely from one stone element.

${ }^{60}$ Conservation works were carried out by Wojciech Osiak in 2015. 

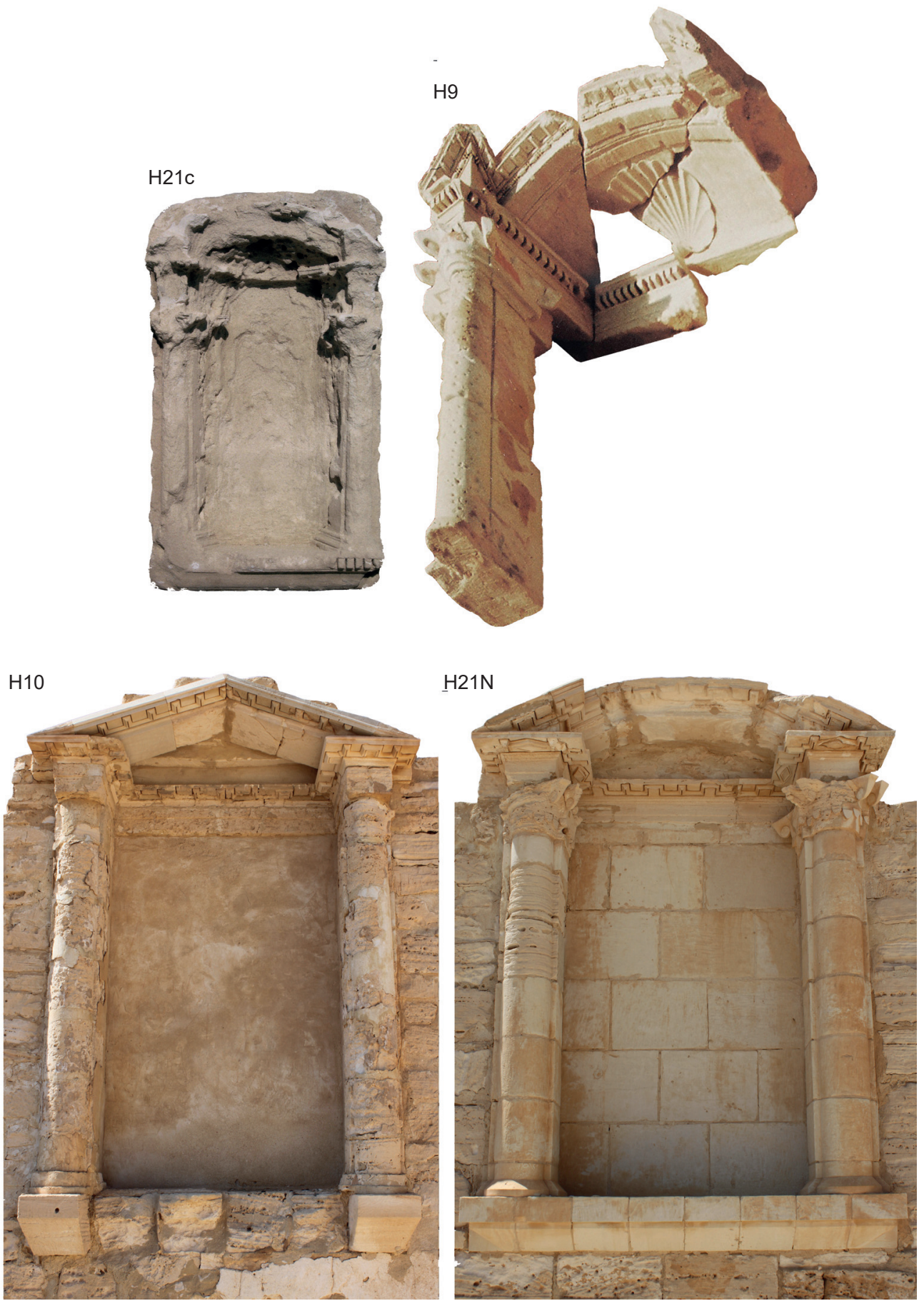

5. Marina el-Alamein. Aediculae from houses H21c, H9, H10, H21N (Phot. R. Czerner, W.A. Daszewski). 


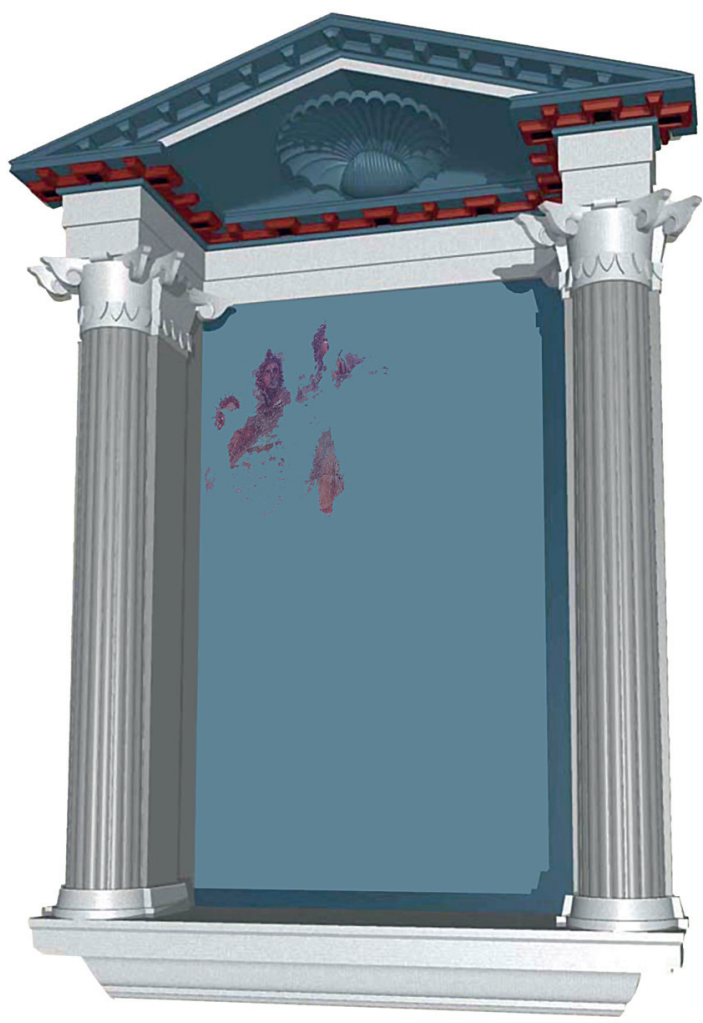

6. Marina el-Alamein. Reconstructed form of the aedicule from house H10 (Processing: R. Czerner).

carved in stone in the finial, nor have any traces of stuccowork survived. However, one might expect that it did in fact exist, considering the similarity of technological workmanship and the scale with the niche from house H10. In addition, elements of four further aediculae have been preserved at the site: a sill, two fragments of a cornice and one with a capital. These elements found out of context during earth and construction work cannot be unequivocally assigned to specific houses. The last three of the above-mentioned elements confirm the same arrangement of architectural framing as in the four reconstructed niches.

The characteristic decorative arrangement of the Marina el-Alamein aediculae in the so-called baroque style allowed a distinctive decorative element to be located in a wellexposed place, centrally in the finial. The shell as a motif of choice does not result from the shape of the niche, as would be the case with recesses closed at the top by a semi-dome. The arrangement is repeated in Marina el-Alamein for all aediculae, either complete ones or those known from individual elements. There were variants that could additionally enhance the baroque character of niche framing, but the basic concept remained unchanged.

The baroque feel of the Hellenistic architecture of Alexandria and the regions under its sway, including the ancient town that once stood where today's Marina el-Alamein lies, is understood as arising from individual elements - columns, cornices, architraves, etc. - losing 

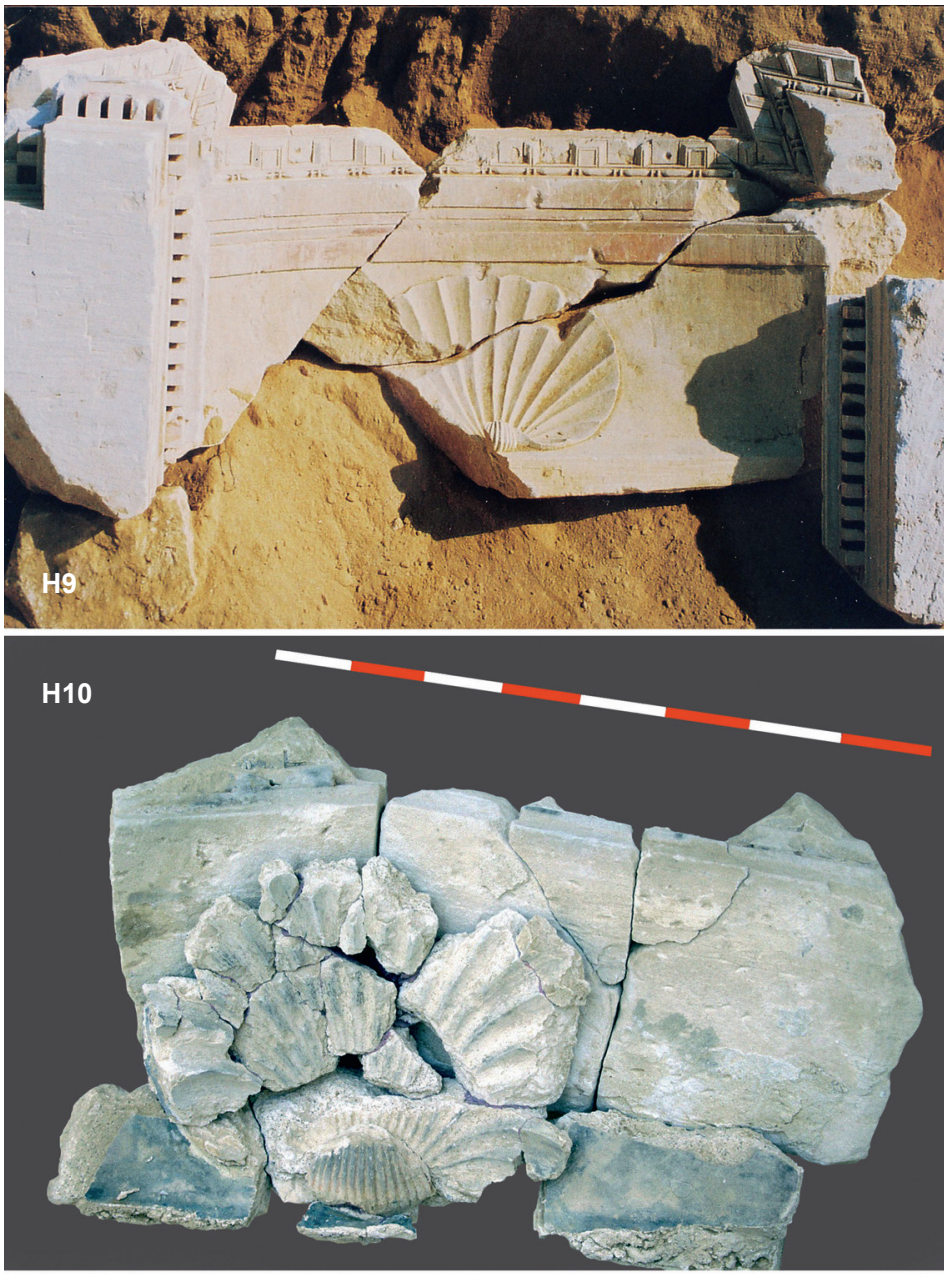

7. Marina el-Alamein. Shell relics from the decorations of aediculae from houses $\mathrm{H} 9$, H10, H21c

(Phot. W.A. Daszewski,

R. Czerner, S. Medeksza).

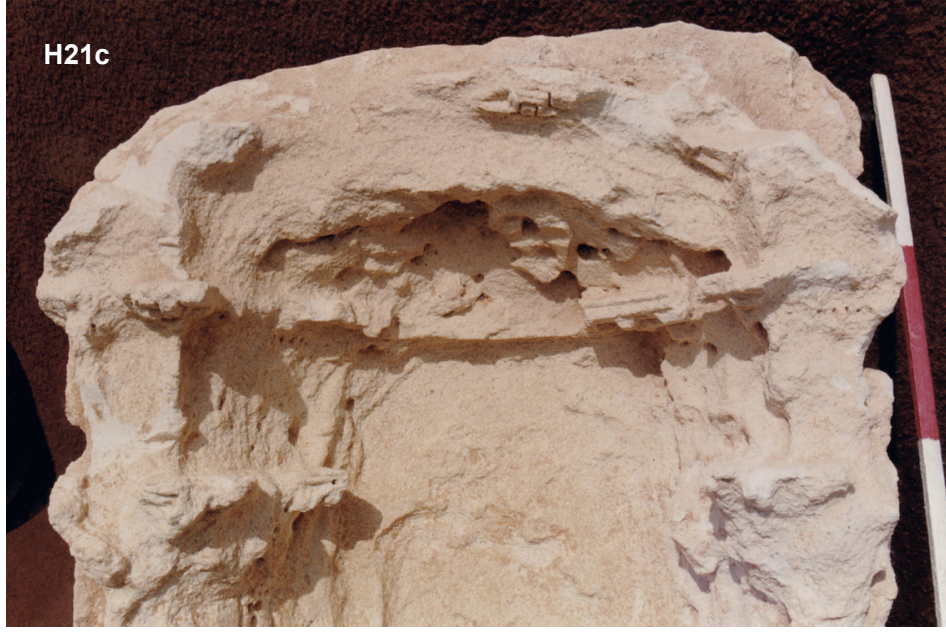




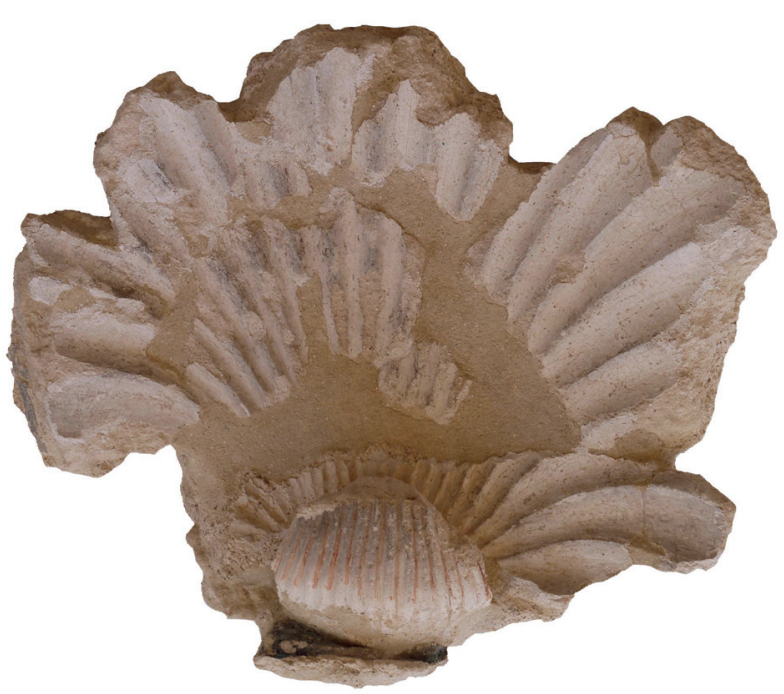

8. Marina el-Alamein. Fragment of the shell decoration of the aedicule from house H10 after conservation (Phot. W. Osiak).

their tectonic and structural design logic, mainly as a result of breaks, setoffs or embedding into the wall so that they become a rich, dynamic surface decorative feature. Typical solutions applied include engaged columns, pilasters, broken cornices and pediments, broken forward pediments and segmental pediments. ${ }^{61}$ Frequently, and in Marina el-Alamein in particular, the dominant character was created by the geometrical stylisation (or simplification) of some elements, mainly capitals ${ }^{62}$ and the use of forms typical of the areas under the Hellenistic sway of Alexandria, such as flat grooved modillions and square hollow modillions. ${ }^{63}$

The baroque architectural aedicula framing from Marina el-Alamein, regardless of the variants that mainly involve the top pediment, had, as mentioned, a fixed repetitive layout. On a fairly prominent sill, supported by a syma, on both sides of the recess stood pseudo-Corinthian half-columns protruding from the wall (Figs 5-6). In the interior of the niche, on its side walls, pilasters with identical forms corresponded to them and directly adjoined them. Above the half-columns and pilasters was an entablature and top pediment. Depending on the variant, this could be triangular (H10), typically Hellenistic and segmental in the baroque style $(\mathrm{H} 9, \mathrm{H} 21 \mathrm{~N})$ or even almost semi-circular $(\mathrm{H} 21 \mathrm{c})$. Its upper cornice could have a straight layout (H10) or with setoffs breaking the line, slightly pulling back the central section $(\mathrm{H} 21 \mathrm{c}, \mathrm{H} 21 \mathrm{~N})$. Finally, its extreme sections could rise steeply in the form of a so-called 'pinion' (H9).

\footnotetext{
61 McKenzie 1996: 116-120; 2007: 92-94.

62 Czerner 2009: especially 2-6, 40-41; Daszewski 1990: 112-119.

63 McKenzie 2007: 83, 94.
} 
The course of the lower cornice is characteristic of Marina el-Alamein aediculae. This one is of particular interest to us as it makes it possible to display shells in the finial of the niche. The cornice did not run straight, parallel to the line of the room wall and repeating the line of the upper cornice. Therefore, they did not form together a closed pediment. The lower cornice just behind the sides of the framing was broken and curved along the side walls of the niche, and then again along its back wall. As such, it circled the niche in a horseshoe layout, revealing the ceiling of the finial or a vault in the form of a dome section. In this large and well-exposed space, a place was created for an expressive decorative element and the focus of our interest - the shell.

The arrangement described is repeated throughout Marina el-Alamein in all known niches, although their sizes range from a tiny one hewn from one limestone block $(0.40 \mathrm{~m}$ high $)$ to one more than five times larger (with half-columns $2.13 \mathrm{~m}$ high). ${ }^{64}$ The proportions of the width to the height of the niche also remain unchanged, and of course others related to the modular arrangement of the architectural design. Preserved shell fragments are also known to have come from aediculae of different sizes and are therefore unrelated to their dimensions.

The Graeco-Roman architecture of Alexandria and other places under its influence seems to have eagerly applied other typical Baroque solutions, mainly cornices and broken pediments, as the known relics would seem to suggest. ${ }^{65}$ Open pediments ${ }^{66}$ are typical and especially well represented in the Marina el-Alamein artefacts. Open pediments are also known for the crowning aediculae, reconstructed on the basis of the preserved elements of the northern inner façade of the Great Peristyle in the Palazzo delle Colonne in Ptolemais. ${ }^{67}$ However, the ceiling there is flat, decorated with a uniform geometric design made of coffers. The semi-dome of the central aedicula of the same façade and its open Syrian-style pediment is decorated in the same way. ${ }^{68}$ In both cases, the opening of the pediments was not used to display one distinct individual decorative element. ${ }^{69}$

Therefore, one might observe that the arrangement with a baroque open pediment, so consistently used in the Marina el-Alamein aediculae, makes it possible to locate a clearly visible sculptural element in the upper part of the niche framing, although this does not imply a shell as a form and motif of this decoration, for example through the shape formed by the contour around the available space. This is the case even with the small aedicula from house $\mathrm{H} 21 \mathrm{c}$, whose segmental pediment is almost semi-circular yet is not filled with a shell, but a much smaller circular one is found in the centre of the semi-dome (Fig. 7). By way of comparison, this instead occurs in other places, e.g. the Pompeian lararia, ${ }^{70}$

${ }^{64}$ Czerner 2005: 129, Fig. 8.

${ }_{65}$ McKenzie 1996: 116-120; 2007: 89-94.

${ }^{66}$ Terminology following McKenzie 2007: Fig. 146b-e.

${ }^{67}$ Bergmann 2008: Fig. 20; McKenzie 2007: 95, Fig. 158; Pesce 1950: 27, Pls 10, 13a; Stucchi 1975: Fig. 310.

${ }_{68}^{68}$ Pesce 1950: Fig. $13 b$.

${ }^{69}$ The peristyle underwent reconstruction in the first and second centuries, but according to McKenzie it has some earlier features, perhaps even from 80 BC, including the aediculae described. Cf. McKenzie 2007: 95.

${ }^{70}$ Giacobello 2008: 67-68. 
as well as other regions, ${ }^{71}$ e.g. Cyrenaica ${ }^{72}$ and several Egyptian examples, ${ }^{73}$ with niches closed at the top with a semi-dome or arcade featuring conchs perfectly described on a semi-circular shell shape. ${ }^{74}$ The semi-dome crowning a domestic niche in House C119 in Karanis is a perfectly described on the shell. ${ }^{75}$

The shell motif, alien to the tradition of Egyptian architecture, became very popular in Roman times, appearing in various forms, including architectural. It first appeared in the early Empire. ${ }^{76}$ In the finials of aedicula from Marina el-Alamein, the shells are perfectly exposed but, as observed above, the shape of the architectural framing does not result from their form, nor vice versa does the use of shells arise from its shape. Thus, despite the very widespread use of shells as decorative features, in architecture mainly as semi-domes, other reasons for including this motif in aediculae should be considered - for example, to apply symbolism that would adhere to the iconographic programme of representations located lower inside the niche.

Such is particularly likely to be the case in house H10, where the pediment covering the niche is triangular in shape, and the shell fitted from below into its ceiling was made of stucco. As much as the shell carved into limestone perfectly fits the ceiling, passing into the dome section of the segmental niche pediment from house $\mathrm{H} 9$ or $\mathrm{H} 21 \mathrm{c}$, its location at the junction of two slabs - at the top of the triangular tympanum - is not obvious and is only possible thanks to the mortar that fills quite a significant space between it and the ceiling (Fig. 7). Leaving a flat ceiling undecorated or, for example, filled with a geometric pattern, as in the aediculae of the Palazzo delle Colonne, would certainly have been a more regular solution in this case and consistent with the geometry of the architectural form. Forms of niche finials similar to those in Marina el-Alamein, segmental with a broken upper cornice of the pediment, as a continuation of Hellenistic design, only survived in Egypt during Christian times, in the fifth and sixth centuries. ${ }^{77}$ However, it is not always a shell that appears in a similar position, but sometimes a different motif.

Despite the irregularity of the solution in the case of the triangular pediment, on the one hand, and the precedents of using other motifs in similar decoration of segmental tympanums, shells were placed in the Marina el-Alamein aediculae. Therefore, this shows that their presence may have been a requisite in this case, and that this need could have been related to symbolism. Placing a round shell of similar form in the middle of the larger conch of the niche from house $\mathrm{H} 21 \mathrm{c}$, without inserting a larger shape that repeats its outline, can also be explained by a requirement beyond the merely decorative.

71 El Fakharani 1965: 58-61.

72 E.g. from graves N28 and N24 in Cyrene. Cf. Stucchi 1975: 317-318, Figs 328, 330.

73 Three semi-domes from Kom el-Shuqafa and one from the tomb at Souk el-Wardian in Alexandria, and one from Roman Funerary House no. 13 in Tuna el-Gebel. Cf. El Fakharani 1965: 57-58, Figs 1-4; Stucchi 1975: 318 .

74 Stucchi 1975: 318.

75 Gazda (Ed.) 2004: 30, Fig. 54.

76 El Fakharani 1965: 58.

77 McKenzie 1996: 120, Fig. 27; 2007: 94, Fig. 507; Bergmann 2008: Fig. 23. 
In this context, some researchers focus on the shell as one of the attributes of Aphrodite and thus explain the presence of this motif in the lararia related to her cult. ${ }^{78}$ This is the interpretation of the shell in the finial of the lararium from the House of Paccius Alexander in Pompeii, where the figures whose stucco representations have been preserved in the relics in the niche can be seen as Aphrodite and Eros on a sea horse. ${ }^{79}$ There is a known case of the statue of the goddess being placed in a niche crowned with a shell, i.e. above it. ${ }^{80}$

That a cult of Aphrodite developed in Marina el-Alamein is confirmed by finds. ${ }^{81}$ The iconographic program of the aediculae from house $\mathrm{H} 21 \mathrm{c}$ in Marina el-Alamein is unknown, although its unique semi-circular plan (trapezoid in its lower section) implies that there was probably a small statue there. Neither do we know the scheme of the decorative painting on the unpreserved back wall of the niche in house $\mathrm{H} 9$, but such a scheme probably did exist, given the preserved remains of polychrome on its pilasters and cornices. In both cases, representations related to the cult of Aphrodite cannot be ruled out. The painted decoration on the back wall of the aedicula from house $\mathrm{H} 10$ has been largely preserved (Fig. 6). Recent studies indicate a strong likelihood that the centrally located figure depicted surrounded by other accompanying deities was Aphrodite Anadyomene. ${ }^{82}$

In his studies of semi-domes in Hellenistic Egypt, Fawzi el Fakharani analysed the forms of the shells decorating them against a wider background, creating their typology and a basis for dating them. ${ }^{83}$ Inter alia, he confirmed Edmund Weigand's observation from 1914 that shells with a hinge at the top could have emerged in Italy, while in the eastern provinces they always had the hinge at the bottom. ${ }^{84}$ In the typology that he developed, a scallop shell such as the three known examples from Marina el-Alamein - i.e. with a fan of ribs and furrows bending downwards towards the outside from the spring, with sharp edges to the furrows (like in Doric fluting) - would be dated early, even to the first century, given that some were found in Herculaneum and Pompeii. ${ }^{85}$ In Marina el-Alamein, the shells and niches are also dated relatively early: in house $\mathrm{H} 9$ - the first century, ${ }^{86} \mathrm{H} 10$ - the first or early second century, ${ }^{87} \mathrm{H} 21 \mathrm{c}$ before AD $180-183^{88}$ and in $\mathrm{H} 21 \mathrm{~N}$ - earlier than $\mathrm{H} 21 \mathrm{c}$. This is also how the lamps featuring shell designs are dated. In the period from the mid-first century and in the second century, this motif enjoyed great popularity among the inhabitants of the coastal town.

${ }^{78}$ Giacobello 2008: 67.

${ }^{79}$ Giacobello 2008: 247.

${ }^{80}$ Cf. a terracotta stela showing Venus Anadyomene, Roman, second-third century AD; see webpage AlexanderAncientArt: stock number $\mathrm{C} 1076$.

${ }^{81}$ Bąkowska-Czerner 2011: 97-100; Daszewski 2013: 168-170.

${ }^{82}$ Czerner, Bąkowska-Czerner 2020: 327.

${ }^{83}$ El Fakharani 1965: 61-62.

${ }^{84}$ Weigand 1914: 64-67.

${ }^{85}$ El Fakharani 1965: 61.

${ }^{86}$ Bąkowska-Czerner, Czerner 2019a: 81, 84.

${ }^{87}$ Czerner, Bąkowska-Czerner 2020: 323-324, 327, Fig. 7.

${ }^{88}$ It was built into the wall of the reception room, where a commemorative monument of Commodus then stood. Cf. Czerner, Medeksza 2010: 98-99; Łajtar 2003: 178. 
Concluding, the special, characteristic arrangement of the baroque decorations of the Marina el-Alamein aediculae created an opportunity to display a distinctive decorative motif in their centre. In known cases, the preserved relics reveal that this was a scallop shell, round or slightly extended horizontally to create an oval form, hinged downwards and with sharp edges between the furrows. Since the shell is one of the main attributes of Aphrodite, whose cult thrived in the ancient town, and the aediculae located in the main reception halls of residential houses had a religious character, it is likely that these shells were part of the iconographic programme of a largely unpreserved decorative scheme associated with the goddess. This thesis is substantiated by the lack of a close relationship or causality between the shape of the architectural framing with the roundness of the shell, and in one case its insertion into a triangular space may be even described as a mismatch. This indicates at least that there could have been an additional reason for choosing the shell motif other than its mere ornamental value and the logic of the decoration.

\section{References}

AlexanderAncientArt: https://www.alexanderancientart.com/1076.php (accessed February 2, 2021)

Andrews, C. 1994: Amulets of Ancient Egypt, London

Bailey, D.M. 1980: A Catalogue of the Lamps in the British Museum 2. Roman Lamps Made in Italy, London

Bailey, D.M. 1988: A Catalogue of the Lamps in the British Museum 3. Roman Provincial Lamps, London

Bailey, D.M. 2001: Lamps from the Sacred Animal Necropolis, North Saqqara and the Monastery of Apa Antinos, JEA 87, 119-133

Bąkowska-Czerner, G. 2011: Aphrodite in Egypt. Images of the goddess from Marina El-Alamein, [in:] Meyza, H., Zych, I. (Eds), Classica Orientalia. Essays Presented to Wiktor Andrzej Daszewski on his 75th Birthday, Warsaw, 97-114

Bąkowska-Czerner, G., Czerner, R. 2019a: House H9 from Marina el-Alamein - a Research Summary, Światowit LVIII, 73-86

Bąkowska-Czerner, G., Czerner, R. 2019b: Marina el-Alamein, Greco-Roman Town in Egypt, [in:] Bąkowska-Czerner, G., Czerner, R. (Eds), Greco-Roman Cities at the Crossroads of Cultures. The $20^{\text {th }}$ Anniversary of Polish-Egyptian Conservation Mission Marina el-Alamein, Oxford, 19-39

Bergmann, M. 2008: Zu den Tempelfassaden im Eingang der Casa del Fauno, [in:] Pirson, F., Wulf-Rheidt, U. (Eds), Austausch und Inspiration. Kulturkontakt als Impuls architektonischer Innovation. Kolloquium vom 28.-30.4.2006 in Berlin anlässlich des 65. Geburtstages von Adolf Hoffmann, Mainz a/Rhein, $113-130$

Bezzola, S. 2004: Lucerne fittili dagli scavi di Palaepaphos (Cipro), Mainz a/Rhein Broneer, O. 1932: Corinth X: The Odeum, Cambridge, Mass.

Bruneau, Ph. 1965: Les lampes, EAD 26, Paris 
Bruneau, Ph. 1971: Lampes corinthiennes, $B C H$ 95/2, 437-501

Bruneau, Ph. 1977: Lampes corinthiennes (II), BCH 101, 249-295

Bussière, J., Wohl, B.L. 2017: Ancient Lamps in the J. Paul Getty Museum, Los Angeles Chrzanovski, L. 2019: Lampes antiques, byzantines et islamiques du Nil à l'Oronte. La Collection Bouvier, Warszawa

Chrzanovski, L., Djaoui D. 2018: A (partial) iconographical dictionary of early Roman Imperial lamps (70-130 AD). A Short Study of 290 discus-motifs adorning the lamps discovered within the harbour garbage covering the "Arles-Rhône 3" shipwreck and of their geographic repartition, Peuce 16, 55-198

Czerner, R. 2005: The anastylosis and conservation of architectural niches in Marina el-Alamein, PAM XVI, 119-130

Czerner, R. 2009: The Architectural Decoration of Marina el-Alamein, BAR-IS 1942, Oxford

Czerner, R., Bąkowska-Czerner, G. 2020: House H10 from Marina el-Alamein on the northwest coast of Egypt, PAM XXIX/2, 311-335

Czerner, R., Bąkowska-Czerner, G., Majcherek, G. 2015: Research and Conservation in the Roman Baths of Marina el-Alamein in the 2012 and 2013 Seasons (PolishEgyptian Conservation Mission), PAM XXIV/1, 113-138

Czerner, R., Medeksza, S. 2010: The Commodus Monument from House H21c in Marina el-Alamein, PAM XIX, 98-113

Daszewski, W.A. 1990: Nouvelles recherches sur la côte Nord de l'Égypte. Un type méconnu de chapiteaux, EtudTrav XV, 109-124

Daszewski, W.A. 1991: The gods of the north-west coast of Egypt in the Graeco-Roman period, MEFRA 103/1, 91-104

Daszewski, W.A. 1995: Cypriot Sigillata in Marina el-Alamein, [in:] Meyza, H., Młynarczyk, J. (Eds), Hellenistic and Roman Pottery in the Eastern Mediterranean. Advances in Scientific Studies. Acts of the II Nieborów Pottery Workshop, Nieborów 18-20 December 1993, Warsaw, 27-39

Daszewski, W.A. 2013: Statues and Statuettes from an Ancient Town in Modern Marina el-Alamein in Egypt, EtudTrav XXVI, 163-172

De Carolis, E., Esposito, F., Falcucci, C., Ferrara, D. 2012: Riflessioni sul quadro della "Venere in Conchiglia" di Pompei: dal mito al lavoro dei pictores, RSP 23, $7-24$

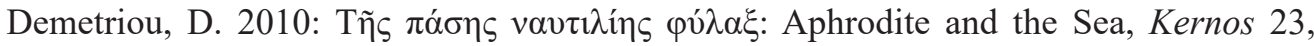
67-89

Deneauve, J. 1969: Lampes de Carthage, Paris

El Fakharani, F. 1965: Semi-Dome Decoration in Graeco-Roman Egypt, AJA 69/1, 57-62

Gazda, E.K. (Ed.), 2004: Karanis, An Egyptian Town in Roman Times: Discoveries of the University of Michigan Expedition to Egypt (1924-1935), Ann Arbor

Giacobello, F. 2008: Larari pompeiani. Iconografia e culto dei Lari in ambito domestico, Milano

Goethert-Polaschek, K. 1985: Katalog der römischen Lampen des Rheinischen Landesmuseums Trier: Bildlampen und Sonderformen, Mainz a/Rhein 
Hemingway, S., Stone, R. 2017: The New York Sleeping Eros: A Hellenistic Statue and Its Ancient Restoration, Technè. La science au service de l'histoire de l'art et de la préservation des biens culturels 45, 46-63

Kadous, E.Z. 1992: Roman Lamps - An unpublished collection in Greco-Roman Museum of Alexandria, [in:] Bonacasa, N., di Vita, A. (Eds), Alessandria e il mondo ellenistico - romano. Studi in Onore di Achille Adriani, Roma, 227-240

Kiss, Z. 2008: Autour de Bérénice, EtudTrav XXII, 76-83

Kousser, R. 2010: Augustan Aphrodites: The Allure of Greek Art in Roman Visual Culture, [in:] Smith, A.C., Pickup, S. (Eds), Brill's Companion to Aphrodite, Leiden-Boston, 287-306

Kucharczyk, R. 2010: Glass from Houses 1 and 2 in Marina el-Alamein, PAM XIX, 114-130

Loeschcke, S. 1919: Lampen aus Vindonissa: Ein Betrag zur Geschichte von Vindonissa und des antiken Beleuchtungswesens, Zurich

Łajtar, A. 2003: The inscription from Marina el-Alamein Commemorating the $\sigma \kappa o v ́ \tau \lambda \omega \sigma 1 \varsigma$

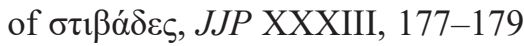

Majcherek, G., Zych, I. 2011: The evidence for Cretan presence in the ancient town of Marina el-Alamein, [in:] Meyza, H., Zych, I. (Eds), Classica Orientalia. Essays Presented to Wiktor Andrzej Daszewski on his 75th Birthday, Warsaw, 357-378

Martin, S.R. 2017: Revisiting the 'Slipper Slapper' and other sculpture dedications in the clubhouse of the Poseidoniasts of Beirut, JGA 2, 253-282

McKenzie, J. 1996: Alexandria and the Origins of Baroque Architecture, [in:] Hamma, K. (Ed.), Alexandria and Alexandrianism. Papers Delivered at a Symposium Organized by the J. Paul Getty Museum and the Getty Centre for the History of Art and the Humanities and Held at the Museum, April 22-25, 1993, Malibu, 109-125

McKenzie, J. 2007: The architecture of Alexandria and Egypt, 300 BC-AD 700, New Haven-London

Medeksza, S. 1999: Marina el-Alamein - Egypt. Polish-Egyptian Mission for Restauration unpublished report, Institute of History of Architecture, Art and Technology, Faculty of Architecture, Wrocław University of Science and Technology, Marina el-Alamein

Młynarczyk, J. 2012: Terracotta Oil Lamps, Tell Atrib 1985-1995 III, Warsaw

Oziol, Th. 1977: Salamine de Chypre VII. Le lampes du Musée de Chypre, Paris

Pesce, G. 1950: Il "Palazzo delle Colonne" in Tolemaide di Cirenaica, Roma

Petrie, W.M.F. 1914: Amulets, London

Rosenthal, R., Sivan, R. 1978: Ancient Lamps in the Schloessinger Collection, Jerusalem

Shier, L.A. 1978: Terracotta Lamps from Karanis, Egypt. Excavation of the University of Michigan, Ann Arbor

Stucchi, S. 1975: Architettura Cirenaica, Roma

Sztetyłło, Z. 1991: Lamps from Marina, [in:] Krzyżanowski, L. (Ed.), Archaeological Background and Conservation Problems. Marina El Alamein 1, Warsaw, 47-50

Theodoropoulou, T. 2013: The sea in the temple? Shells, fish and corals from the sanctuary of the ancient town of Kythnos and other marine stories of cult, [in:] Ekroth, G., Wallensten, J. (Eds), Bones, behaviour and belief. The zooarchaeological 
evidence as a source for ritual practice in ancient Greece and beyond, Stockholm, $197-222$

Vallois, R. 1929: Le temple délien d'Arsinoé Philadelphe ou d'Agathè Tychè, CRAIBL $73 / 1,32-40$

Walters, H.B. 1914: Catalogue of the Greek and Roman Lamps in the British Museum, London

Weigand, E. 1914: Baalbek und Rom, die römische Reichskunst in ihrer Entwicklung und Differenzierung, JDAI 29, 37-91

Wypustek, A. 2014: The Sleep of Eros in a Funerary Epigram from Tomis (Peek, Griechische Vers-Inschriften no. 1942), [in:] Twardowska, K., Salamon, M., Sprawski, S., Stachura, M., Turlej, S. (Eds), Within the Circle of Ancient Ideas and Virtues. Studies in Honour of Professor Maria Dzielska, Kraków, 77-84

Zych, I. 2004: Marina el-Alamein. Some Ancient Terracotta Lamps from Marina, PAM XV, 77-90 


\section{ÉTUDES et TRAVAUX XXXIV / 2021}
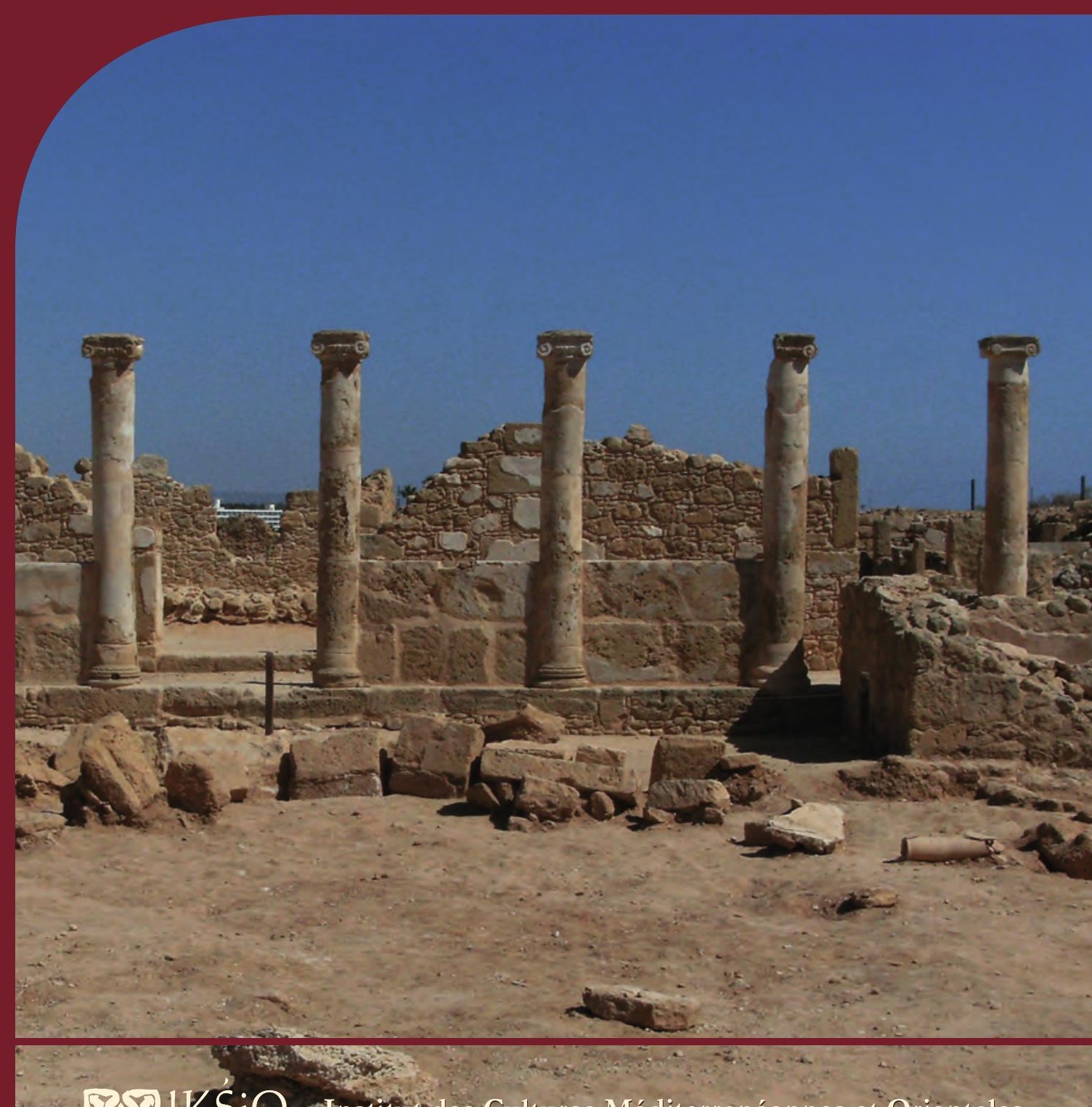

W $92 \mathrm{HKSiO}$ Institut des Cultures Méditerranéennes et Orientales

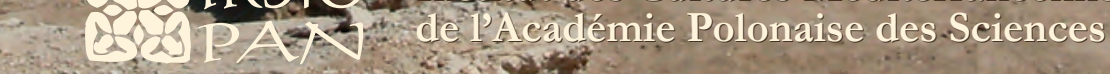

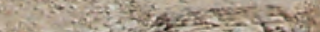

Q 
COMITÉ DE RÉDACTION SCIENTIFIQUE

Maciej Makowski - rédacteur en chef

Jadwiga Iwaszczuk - rédacteur

Katarzyna Kapiec - secrétaire de la rédaction

Henryk Meyza - rédacteur thématique du volume

CONSEIL SCIENTIFIQUE DU JOURNAL

M. Kobusiewicz (IAE PAN, Warszawa)

E. Laskowska-Kusztal (IMOC PAS, Warszawa)

D. Michaelides (University of Cyprus, Nicosia)

J.Ch. Moretti (IRAA-MOM, Université de Lyon 2/CNRS)

D. Raue (Ägyptisches Museum der Universität Leipzig)

P. Reynolds (ICREA, España)

D. Welsby (British Museum, London)

COMITÉ SCIENTIFIQUE DE LECTURE

la liste des membres du comité est accessible en ligne sur

http://www.etudesettravaux.iksiopan.pl

RÉDACTION TECHNIQUE

Marta Kaczanowicz

REVUE DES TEXTES EN ANGLAIS

Jo Harper 
ÉTUDES et TRAVAUX XXXIV 
INSTYTUT KULTUR ŚRÓDZIEMNOMORSKICH I ORIENTALNYCH POLSKIEJ AKADEMII NAUK

\title{
STUDIA i PRACE
}

\section{XXXIV}

\author{
GoIKSiO \\ QSO PAN \\ WARSZAWA \\ 2021
}


INSTITUT DES CULTURES MÉDITERRANÉENNES ET ORIENTALES DE L’ACADÉMIE POLONAISE DES SCIENCES

\section{ÉTUDES et TRAVAUX}

XXXIV

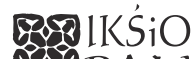

EOSPAN

VARSOVIE

2021 
Publication scientifique financée dans le cadre du programme du Ministre de la Science et de l’Éducation Supérieure

« Programme National de Développement de l’Humanistique » pour les années 2016-2021 (projet no 3bH 150099 83)

\title{
(1) NARODOWY PROGRAM ROZWOJU HUMANISTYKI
}

\author{
Copyright $(C)$ \\ Instytut Kultur Śródziemnomorskich i Orientalnych PAN \\ et les Auteurs \\ Warszawa 2021
}

ISSN 2084-6762

(jusqu'en 2011 : 0079-3566)

e-ISSN 2449-9579
Version première en papier, imprimée en Pologne - 150 copies
Version électronique accessible sur
http://www.etudesettravaux.iksiopan.pl

Édition: Polskie Towarzystwo Historyczne et Wydawnictwo Neriton, Warszawa

Conception générale de la couverture : J. Iwaszczuk

Photographie de couverture : Phot. A. Brzozowska-Jawornicka

(Le portique ionique est, péristyle de la Maison « hellénistique », Nea Paphos) 


\section{Table des matières}

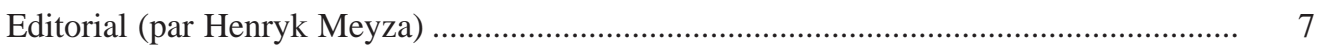

Marta BaJTLER

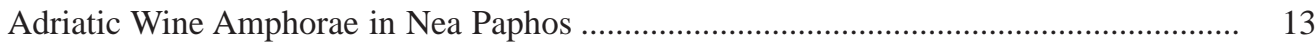

Claire Balandier, Jolanta MlynarczyK

The Temple and Its Surroundings on Fabrika Hill, Paphos: Preliminary Results

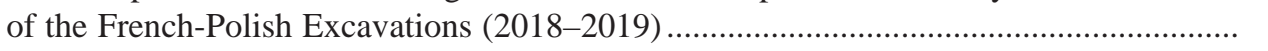

Grażyna BĄKowska-Czerner, Rafal CzERner

The Shell Motif in the Culture and Architecture of the Ancient Town of Marina el-Alamein in Egyp

AleKsandra BrzozowsKa-JaWornicKa

'Hellenistic' House in Nea Paphos, Cyprus - A First Summary of Its Architecture.

AleKsandra BrzozowsKa-JaWORnicKA, AnNa KuBICKA-SowińsKa

In Search of the Module in the Architectural Design of the 'Hellenistic'

House in Nea Paphos, Cyprus

RoKsana HaJduga

Kushite Stamp Impressions from Selib 2, Sudan

ERSIN HusSEIN

Mapping Metal Rich Roman Cyprus: The Case for Object-Centred Approaches

BARBARA LICHOCKA

Villa of Theseus at Nea Paphos (Cyprus). Fourth-Early Fifth Century Numismatic

Evidence for Architectural Transformations and Seismic Events

VASiliki Lysandrou, Demetrios Michaelides

Wall Paintings in Ancient Cyprus: The Hellenistic and Roman Tombs of Paphos

and Its Region

ADAM ŁAJTAR

A Weight of Seleucia in Pieria in Nea Paphos

Diana MroczeK

Ancient Portrait Busts of Marcus Aurelius in the National Museum in Poznań 
Brandon R. Olson, R. Scott Moore, Thomas Landvatter, Justin Stephens

Pyla-Vigla: A Case Study Assessing the Imperial Strategies of the Hellenistic

Diadochoi in Cyprus

Patrizio Pensabene, Eleonora Gasparini

Colonnaded Hall in Kourion: How the Oecus Corinthius Was Interpreted in the Roman

Houses of Cyprus

Monika Rekowska, Demetrios Michaelides, Skevi Christodoulou, JAKUB KANISZEWSKI

Adopting Roman Habits - The Baths in the House of Orpheus in Nea Paphos

as a 'Troublesome' Case Study?

MARCIN M. ROMANIUK

Terracotta Pipelines at Maloutena: Remarks on the Water System in the

Residential District of Ancient Nea Paphos, Cyprus

363

ABRÉVIATIONS

407 